\title{
Student Perceptions of Mobile Learning Based Guidebooks
}

\author{
Darmaji, Dwi Agus Kurniawan*, Astalini, Rahmat Perdana, Artha Lumbantoruan, Nengria Nasih, \\ Sofiah Christine Samosir, Utari Prisma Dewi
}

Faculty of Teaching and Education, Universitas Jambi, 36361, Jambi, Indonesia

Received April 10, 2020; Revised September 30, 2020; Accepted October 19, 2020

\section{Cite This Paper in the following Citation Styles}

(a): [1] Darmaji, Dwi Agus Kurniawan, Astalini, Rahmat Perdana, Artha Lumbantoruan, Nengria Nasih, Sofiah Christine Samosir, Utari Prisma Dewi , "Student Perceptions of Mobile Learning Based Guidebooks," Universal Journal of Educational Research, Vol. 8, No. 11B, pp. 5686 - 5692, 2020. DOI: 10.13189/ujer.2020.082202.

(b): Darmaji, Dwi Agus Kurniawan, Astalini, Rahmat Perdana, Artha Lumbantoruan, Nengria Nasih, Sofiah Christine Samosir, Utari Prisma Dewi (2020). Student Perceptions of Mobile Learning Based Guidebooks. Universal Journal of Educational Research, 8(11B), 5686 - 5692. DOI: 10.13189/ujer.2020.082202.

Copyright $\mathrm{C} 2020$ by authors, all rights reserved. Authors agree that this article remains permanently open access under the terms of the Creative Commons Attribution License 4.0 International License

\begin{abstract}
This study aims to look at differences in students' perceptions about the use of mobile-based practicums. This type of research is a mixed method, involving 117 students with 59 students in the physics education study program and 58 students in the chemistry education study program. Data collection uses an interview and perception questionnaire about mobile-based practicum guides using a Likert scale of 5 , for data analysis using descriptive and inferential statistics in the form of an independent sample t-test. Based on the results of data analysis from the perception questionnaire produced for the basic physics practicum guide based on mobile learning, it can be concluded that the basic physics practicum guide based on mobile learning has a positive response, which was given by physics education study program students and Chemistry study program students with the perception results of educational study programs physics included in the frequency category 38 and the percentage are $64.4 \%$. And for the perception of chemistry study programs, it is also included in the good category contained at frequency 28 with a percentage of $48.3 \%$. There are differences in the two classes, and physics education students have a dominant category better than chemistry education students as shown by the t-test conducted. Therefore, it is recommended to use technology in the learning media to be taught, because it has various advantages in using it.
\end{abstract}

Keywords Perception, Practicum Guide, Mobile Learning

\section{Introduction}

The rapid development of technology has led to a variety of new applications, such as smartphones. Presently, the smartphone has become an obligatory requirement among students. According to [1], the development of technology can also be used as a learning medium that can support the learning process. In 2016 the Indonesian Internet Network Providers Association (APJII) surveyed the results showing that $89.7 \%$, the largest internet users in Indonesia were students. The problem that needs to be addressed by educators is to direct students to better use the internet in the realm of education [2]. An example that still uses the internet a little is a basic physics course.

Physics is a science that is in contact with everyday life and scientific formulas and concepts. The physics education study program is one of the study programs which are available in a faculty of the teacher and education which aims to produce skilled graduates in various aspects of competence such as knowledge, understanding, and skills [3-5]. According to [6] for problem-solving can be carried out by guiding students to apply the existing knowledge in themselves. Transferable skills can be developed through the science learning process in classrooms or practicum in laboratories $[7,8]$. Basic physics is a compulsory subject in the Physics 
Education Study Program at the University of Jambi and weighs 4 SKS (3 SKS face to face and 1 SKS practicum). Basic Physics Practicum aims to assist students in solving problems of natural phenomena and train students' science process skills (SPS). Practicum activities are one of the methods used to clarify the material that has been learned. In order for practicums to be carried out, clear and easy practical guidelines are needed to use them.

The practicum guide is used as a reference for practicum both for students and for teaching assistants especially in reflecting material. The initial assignment or preliminary task is a way to study the experimental guide and related material before the practicum begins. The basic Physics practicum guide used today is a guide that can train students' science process skills. Practical activities require science process skills owned by students such as: formulating hypotheses; formulate a problem; identifying variables and analyzing data, and draw conclusions so as to find knowledge in achieving learning competence $[9,10]$. A student's scientific skills process such as identifying problems, building hypotheses, observing, concluding, choosing methods, identifying variables, controlling variables, and making conclusions must explain the level of scientific creativity of students. Several studies have found this relationship between SPS and SC [11]. Students' science process skills are important skills to develop in education [12]. Process skills are also considered a scientific method used to train students' steps in finding things through experimental activities [13]. The observed aspects of science process skills (SPS) include observing, predicting, measuring, using tools, doing work, interpreting data, communicating, and concluding. Science process skills are highly demanded to be possessed by students in the learning process. Because understanding concepts and SPS are an important thing to have, the problems that arise in understanding concepts and SPS experienced by these students must be dealt with as soon as possible by a physics lecturer [14]. The use of basic physics practicum guides that are able to train student SPS greatly helps students in the process of carrying out practical work.

In addition to practicums, guides can train students' science process skills. The use of media can also help students in the learning process. [15] the learning process requires an interesting and enjoyable learning media as a source of independent learning for students. A media and practical guide can overcome the limitations in the implementation of the practicum, so students get their learning experience [16]. Media is a communication channel. Derived from the Latin word meaning "between," this term refers to something that carries information [17]. Media are forms of communication, both in printed form and in audiovisual form and its equipment. Media that is able to provide information precisely between the recipient of the information and the giver of information is a good medium [18]. With the media supporting the learning process, this will facilitate both educators and students in carrying out learning and have a positive impact on students in the implementation of learning, learning media need to facilitate educators [19]. Learning media that are widely used today, namely smartphones, are used not only for communication devices, but also as media for learning [20]. As time develops, both in the field of media technology and the media used for learning will also develop. The past few decades, humans have experienced a revolution in the computer sciences, not only in terms of their ability but also in terms of its use [15].

In line with the industrial revolution 4.0, various technologies have developed widely. The concept of Industry 4.0 assumes blurring the differences between the work of people and the work of machines [21]. The use of technology in the learning process in the current era is mushrooming everywhere, one of which is smartphone-based learning media. The technology is widely used as a learning medium, so it is very supportive of the learning process. According to [22] currently, education in Indonesia is much influenced by the industrial revolution 4.0, namely technology, information, and communication. In the field of education, the use of technology is focused on improving the quality of learning so as to improve the quality of education $[23,24]$. Over the last few decades, information and communication technologies have improved greatly and the use of computers has become more widespread [24]. Through various advantages in the use of technology possessed, one of which is computer technology has inspired many experts in the field of education to empower it on a broader scale, so that the process of use is not limited to learning, but also becomes the main tool in the administration of education [25]. The use of technology to be used as a learning medium is no stranger to today. With that, the researcher wants to see the students' perception of the Basic Physics practicum guide based on mobile learning.

Perception is a process of students' interpreting, evaluating, accepting, giving opinions, and testing the data and sensory responses to what they see [26]. Students' perceptions usually occur during the learning process in the class both perceptions of learning materials, learning models used and the media used [27]. The influence on the social environment in which the individual lives can cause someone's perception to arise. Several studies have shown that m-learning applications can facilitate students in various ways; e.g., by creating ease in learning content and interacting with others, anytime and anywhere [28]. M-learning is learning that utilizes technology and mobile devices [28-30]. So the use of mobile learning can help students become better at learning. Innovative mobile learning makes the learning process easier and more attractive so it is effective for learning [29]. Researchers and relevant instructors need to pay more attention to how to effectively make use of mobile tools or learning strategies to attain good learning effects, or what kind of mobile learning in physical education will be the 
development trend in the future [30].

According to [31] the research team observed the course of the learning process in the form of practicum using observation sheets. The Observation Sheet and Basic Physics Practicum Guide used today are still in the form of hard copy. The use of Observation Sheets and practical guides are less effective and efficient so as to make it easier to use the media as a support for the learning process. In addition to being less effective and efficient, the current practicum guides also spend a lot of paper so as to minimize the use of paper, the solution is to use observation sheets and basic physics practicum guides in the form of mobile learning. Since at this time students, in general, have been using smartphones to support the science process skills students can use observation sheets and basic physics practicum guides based on mobile learning that can be used anytime and anywhere so that students can prepare themselves in advance for practical activities. Therefore, to facilitate the implementation of practicum and increase students' insight, researchers consider looking at students' perceptions of the application of basic physics practicum guides based on mobile learning.

Therefore, the aim of this study is to look at differences in the perceptions of physics and chemistry students in using mobile-based practicum guides, with the following research questions

1. How are students' perceptions of using mobile-based physics practicum guides?

2. Is there a difference between physics and chemistry students in practicing using a mobile-based practicum guide?

\section{Materials and Methods}

\section{Research Design}

This study uses a mixed methods approach. Mixed methods can refer to the use of quantitative and qualitative data in answering research questions as well as being part of a larger research program and is designed as a complement to providing information related to different methodological approaches [32]. The type used is sequential explanatory.

\section{Subject of Study}

In this study students' perceptions were viewed in terms of perceptions of the variables of basic physics practicum based on mobile learning at FKIP Jambi University. This study involved 117 students, consisting of 59 students of physics education study programs and 58 students of chemical education study programs.

\section{Instrument and Data Collection}

Data collection uses an interview and perception questionnaire, questionnaire with five answer choices guided by the Likert scale with the categories of strongly agree, agree, doubt, disagree, and strongly disagree. The questionnaire was made through Google form technology which was then distributed using social media. Google software is a form that is easily accessible, free to use, simple to operate, and good enough to be developed as an evaluation tool in the learning process [33]. In addition to using the questionnaire perception data collection also uses a structured interview sheet that is accompanied by reasons (see figure 1). The questionnaire items of students' perceptions of the basic physics practicum guide based on mobile learning were 10 statements with each positive and negative statement having 5 answer options with Cronbach alpha 0.79. Student responses are expected from the questionnaire in the form of answers agree or disagree with giving a score for each positive statement as follows: Very $\operatorname{Good}=5, \operatorname{Good}=4$, Enough $=3, \operatorname{Not} \operatorname{Good}(\mathrm{ST})=2$, Very Not Good $=1$. Scoring for each negative statement as follows: Very Good = 1, Good = 2, Enough $=3$, Not Good $=4$, Very Not Good $=5$. The level of students' perception categories towards the basic physics practicum guide can be seen in the following Table 1:

Table 1. Levels of student perception categories

\begin{tabular}{cc}
\hline Category & Score Interval \\
\hline Very Not Good & $20.0-36.0$ \\
Not Good & $36.1-52.0$ \\
Enough & $52.1-68.0$ \\
Good & $68.1-84.0$ \\
Very Good & $84,1-100,1$ \\
\hline
\end{tabular}

Data analysis techniques using descriptive statistics obtained mean (M), median (Mo), maximum value and minimum value of perception, and using independent sample t-test.

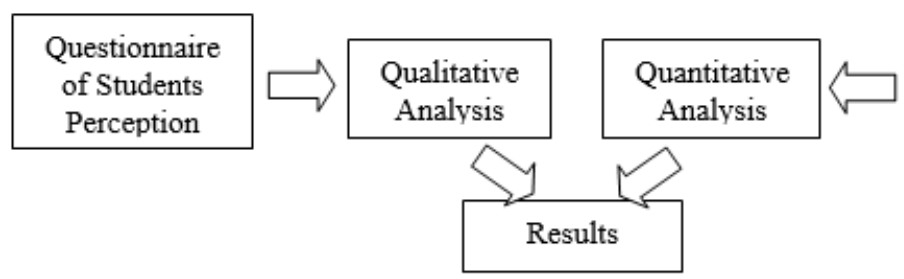

Addition question of interview toward students perception about mobile learning based guidelines

Figure 1. Data Collection 
Table 2. Description of Perceptions About Mobile Learning Based Guidelines

\begin{tabular}{|c|c|c|c|c|c|c|c|c|c|}
\hline \multicolumn{4}{|c|}{ Classification } & \multirow{2}{*}{ Mean } & \multirow{2}{*}{ Median } & \multirow{2}{*}{ Mode } & \multirow{2}{*}{ Min } & \multirow{2}{*}{$\operatorname{Max}$} & \multirow{2}{*}{$\%$} \\
\hline Department & Score Interval & Category & Total & & & & & & \\
\hline \multirow{6}{*}{ Physics } & $20.0-36.0$ & Very Not Good & 0 & \multirow{5}{*}{71.1695} & \multirow{5}{*}{74.0000} & \multirow{5}{*}{$72.00^{\mathrm{a}}$} & \multirow{5}{*}{49.00} & \multirow{5}{*}{91.00} & 0 \\
\hline & $36.1-52.0$ & Not Good & 3 & & & & & & 5.1 \\
\hline & $52.1-68.0$ & Enough & 13 & & & & & & 25.4 \\
\hline & $68.1-84.0$ & Good & 38 & & & & & & 64.4 \\
\hline & $84.1-100.0$ & Very Good & 3 & & & & & & 5.1 \\
\hline & Total & & 59 & & & & & & 100 \\
\hline \multirow{6}{*}{ Chemistry } & $20.0-36.0$ & Very Not Good & 0 & \multirow{5}{*}{70.3621} & \multirow{5}{*}{71.5000} & \multirow{5}{*}{$76.00^{\mathrm{a}}$} & \multirow{5}{*}{49.00} & \multirow{5}{*}{85.00} & 0 \\
\hline & $36.1-52.0$ & Not Good & 1 & & & & & & 1.7 \\
\hline & $52.1-68.0$ & Enough & 24 & & & & & & 41.4 \\
\hline & $68.1-84.0$ & Good & 28 & & & & & & 48.3 \\
\hline & $84.1-100.0$ & Very Good & 5 & & & & & & 5.1 \\
\hline & Total & & 58 & & & & & & 100 \\
\hline
\end{tabular}

Table 3. The results of the Independents sample t-test

\begin{tabular}{cccccccc}
\hline & $\mathrm{T}$ & $\mathrm{N}$ & Mean & Std.Deviation & \multicolumn{2}{c}{ 95\% confidence interval } \\
\cline { 5 - 8 } & & & & & & Lower & Upper \\
\hline \multirow{2}{*}{ Perception Students } & 16.473 & 117 & 3.0906 & .14321 & & 18.236 & .6120 \\
& 16.473 & 108.267 & 2.2033 & .20015 & 17.935 & .8615 \\
\hline
\end{tabular}

\section{Results and Discussion}

Description of student perception data about basic physics practicum guides based on mobile learning can be seen in the Table 2 .

Table 2 shows that the scores obtained from 117 students with valid data acquisition for students' perceptions about the basic physics practicum guide based on mobile learning with a minimum value of physics education study program is 49.00 , a maximum score of 91.00 with an average of 71.1695 , median 74.0000 , mode 72.00 and minimum value of chemistry study program is 49.00 maximum value 85.00 with an average of 70.3621 , median 71.5000 , and mode 76.00 .

Based on table 2, it can be seen that there are dominantly different perception results, namely physics students have a dominant perception with a good category compared to chemistry education students in practicing using a mobile-based guide, to strengthen it can be seen in the independent t-test test in table 3 follows.

From table 3 it can be seen that the value obtained ( $t$ arithmetic) with the value of $t$ table. T-table values can be found in the $\mathrm{t}$ table with a significance value of 0.025 (2-tailed test) with a degree of freedom (df) 117. In this study, the results for t table are 1.97658, whereas the value of $t$ arithmetic can be seen in Table 3 . (column $t$ ) which is 16,473 . The hypothesis testing criteria is that there is a rejection value of $\mathrm{H} 0$ [33]. So, it can be concluded that there are significant differences in the perception of physics students with chemistry in practicing using a mobile-based guide. It can be seen from Table 3 that the average value of students 'perceptions is 3.0906, which means it can improve students' perceptions of practicing.

Based on the results of these data it can be interpreted that the basic physics practicum guide based on mobile learning is feasible to use. The results obtained are in accordance with research conducted by [34], based on the results and responses of students' teaching and learning processes using the developed mobile learning device, the product in terms of feasibility can be said to be very good and has a good level of interactivity and is able to make students active in practicum.

There are differences in perceptions of students of physics education study programs that are higher compared to chemistry education study programs against basic physics practicum guides based on mobile learning because when filling out questionnaires the perception of answers from chemistry students is still doubtful so that chemistry study program students are in the good category with a percentage of $48.3 \%$. Whereas more physics study programs answered that they agreed with the use of basic physics practicum guides based on mobile learning so that physics education study program students were in the good category with a percentage of $64.4 \%$. In other words, physics education students have the desire to use basic physics practicum guides based on mobile learning. According to [18], mobile learning is presented to overcome a problem in learning activities, which is useful to facilitate and provide a way for students to be able to understand the material explained by the lecturer. 
Based on interviews with 22 students consisting of 13 physics education students and 9 chemistry education students, from the interviews obtained information that $100 \%$ of physics and chemistry education students have a smartphone/tablet PC with an Android type. E-learning as a medium that uses the internet, including e-learning is the use of internet technology to deliver a series of solutions that can increase knowledge and skills. E-learning or internet enables learning to use teaching methods and technology as a means of learning. According to them, the use of smartphones (android) is a necessity in the present. The interviews also obtained information that the use of smartphones can help students to study wherever and whenever, and can increase student knowledge. Students also said they preferred learning media by using smartphones (Android) because the students considered their use to be more practical, accessible anywhere and anytime, as well as more, introducing students to ICT technology in learning. In line with research conducted by [35-39], an android application is used as one of the media to facilitate students to find information and understand the concept of optical devices. The reason students prefer learning media using Android is that it is easy to use, can be accessed at any time, and introduces students to ICT technology in learning. Based on the results of the interview, it can be said that the use of basic physics practice based on mobile learning is included in the good category because the response of the average student answers positive choices for the interview sheet accompanied by reason [40-43].

\section{Conclusions}

Based on the results of data analysis from the perception questionnaire produced for the basic physics practicum guide based on mobile learning, it can be concluded that the basic physics practicum guide based on mobile learning has a positive response, given by physics education study program students and Chemistry study program students with the perception results of educational study programs physics is included in the frequency category 38 and the percentage are $64.4 \%$ and for the perception of chemistry study programs it is also included in the good category contained at frequency 28 with a percentage of $48.3 \%$. And there are differences in these two classes, and physics education students have a dominant category better than chemistry education students as shown by the t-test conducted. Therefore, it is recommended to use technology in the learning media to be taught, because it has various advantages in using it.

\section{Acknowledgments}

We thank the chair of the Physics Education study program for giving us the opportunity to work together.
We would also like to thank the head of the Physics Education laboratory at Jambi University, who has provided the opportunity to be able to conduct research at the Jambi University Physics Education laboratory. In addition, thank you to all Physics Education students who participated in this study.

\section{REFERENCES}

[1] U. Cahyana., M. Paristiowati, M. F, Nurhadi \& S. N, Hasyrin. "Studi Tentang Motivasi Belajar Siswa Pada Penggunaan Media Mobile Game Base Learning Dalam Pembelajaran Laju Reaksi Kimia,” Jurnal Teknologi Pendidikan, Vol. 19, No.2, pp. 143-155, 2017

[2] Saifuddin. M. F. "E-Learning dalam Persepsi Mahasiswa., "Jurnal VARIDIKA, Vol. 29, No. 2, pp.102-109, 2018.

[3] S. S, Edie., H. N, Safitri., D. Alighiri., L. M. E. K, Sari., P. Marwoto., \& R. S, Iswari. "The effect of using bomb calorimeter in improving science process skills of physics students," Journal of Physics: Conference Series, Vol. 983, No. 1, 2018.

[4] Darmaji, D. A, Kurniawan., H. Parasdila., \& Irdianti, "Description of Science Process Skills' Physics Education Students at Jambi University in Temperature and Heat Materials," The Educational Review, USA, Vol.2, No.9, pp. 485-498, 2018.

[5] D. Young, Hugh., A. Freedman, Roger., T. R, Sandin., \& F, A. Lewis, "Fisika Universita Edisi Kesepuluh Jilid," Jakarta: Erlangga, 2002.

[6] A. Maliki., I. Maksum., A. Hidayat., \& S. Sutopo, "Kemampuan Pemecahan Masalah Siswa pada Topik Suhu dan Kalor melalui Pembelajaran Cognitive Apprenticeship", Jurnal Pendidikan: Teori, Penelitian, dan Pengembangan, Vol.2, No.2, pp. 304-308, 2017.

[7] A. Setiawan., A. Malik., A. Suhandi., \& A. Permanasari, "Effect of Higher Order Thinking Laboratory on the Improvement of Critical and Creative Thinking Skills," IOP Conference Series: Materials Science and Engineering, Vol. 306, No.1, 2018.

[8] Maison, Darmaji, Astalini, D. A. Kurniawan, and P. S. Indrawati, "Science process skills and motivation," Humanit. Soc. Sci. Rev, Vol.7, No.5, pp. 48-56, 2019.

[9] R. Kustijono., B. Jatmiko., \& M. Ibrahim. "The Effect of Scientific Attitudes toward Science Process Skills in Basic Physics Practicum by Using Peer Model," International Journal of Geomate, Vol. 15, No. 50, pp. 82-87, 2018.

[10] M. Misbah., M. Wati., \& M. F, Rif'at. "Pengembangan Petunjuk Praktikum Fisika Dasar I Berbasis 5M Untuk Melatih Keterampilan Proses Sains dan Karakter Wasaka," Jurnal Fisika Flux: Jurnal Ilmiah Fisika FMIPA Universitas Lambung Mangkurat, Vol. 15. No. 1, pp. 26-30, 2018.

[11] G. Ozdemir., \& A. Dikici, "Relationships between scientific process skills and scientific creativity: Mediating role of nature of science knowledge," Journal of Education in Science Environment and Health, Vol.3, No. 1, pp. 52-68, 
2017.

[12] R. Rahmawati., S. K, Handayanto., \& I. W, Dasna. "Pengaruh Learning Cycle 5E terhadap Keterampilan Proses Sains Peserta Didik Kelas VIII," Jurnal Pendidikan: Teori, Penelitian, dan Pengembangan, Vol. 3, No. 3, pp. 286-290, 2018.

[13] Darmaji, D. A. Kurniawan, Astalini, W. Kurniawan., K. Anwar, \& A. Lumbantoruan, "Students' Perceptions of Electronic's Module in Physics Practicum," Journal of Education and Learning (EduLearn), Vol. 13, No. 2, pp. 288-294, 2019.

[14] A. Yadaeni., S. Kusairi., \& P. Parno. "Penguasaan Konsep dan Keterampilan Proses Sains Siswa Kelas XII pada Materi Fluida Statis," Jurnal Pendidikan: Teori, Penelitian, dan Pengembangan, Vol. 3, No. 3, pp. 357-364, 2018.

[15] A. Astalini., D. A, Kurniawan., U. Sulistiyo., \& R. Perdana. "E-Assessment Motivation in Physics Subjects for Senior High School," International Journal of Online and Biomedical Engineering (iJOE), Vol. 15, No. 11, pp. 4-15, 2019

[16] N. Limatahu., N. Aulia Rahman., S. H, Nur Abu., \& I. Cipta, "Pengaruh Video Praktikum Dengan Modul Elektronik Terhadap Keterampilan Proses Pada Materi Stoikiometri Siswa Kelas X SMAN 2 Tidore Kepulauan," Jurnal Pendidikan Kimia, Vol. 9, No.1, pp. 225-228, 2017.

[17] R. L, Heinich, J. D, Molenda, Russell, "Instructional Media and Technologies for Learning," New Jersey: Merril Prentice Hall, 2002.

[18] R. A, Pratama., S. Ulfa., \& D. Kuswandi. "Mobile Learning Berbasis Game Based Learning Pelajaran Matematika Pokok Bahasan Bangun Ruang Sisi Datar," Jurnal Pendidikan: Teori, Penelitian, dan Pengembangan, Vol. 3, No. 6, pp. 771-777, 2018.

[19] A. M, Zulika., M. H, Wijaya., U. Masitoh., S. Utari., \& T. Titin. "Profil Ketrampilan Proses Sains (KPS) Siswa Dalam Menggunakan Ragam Media Pembelajaran Gerak Melingkar Di Sma,” Wapfi (Wahana Pendidikan Fisika), Vol. 3, No.1, pp. 80-84, 2018.

[20] I. Hasanah., A. Hasani., A. Fatah., I. J, Sari., \& A. Romdani,. "The Influence of Learning by Smartphone to the Conceptual Science Knowledge and the Independence of Students' Learning at Junior High School," Jurnal Penelitian dan Pembelajaran IPA, Vol. 4, No. 2, pp. 158-166, 2018.

[21] B. Ślusarczyk. "Industry 4.0: are We Ready?", Polish Journal of Management Studies, Vol. 17, No. 1, pp. 232-248, 2019 .

[22] Asrial., Syahrial., D. A. Kurniawan., R. Perdana., P. Nugroho, P. Supporting Technology 4.0: Ethnoconstructivist Multimedia for Elementary Schools. International Journal of Online and Biomedical Engineering (iJOE). 15(9), 4-15. 2019

[23] Asrial, Syahrial., D. A, Kurniawan., F. Chan., R. Septianingsih., \& R. Perdana. "Multimedia Innovation 4.0 in Education: E-Modul Ethnoconstructivism", Universal Journal of Educational Research, Vol. 7, No. 10, pp. 2098-2107, 2019

[24] A. Astalini., D. Darmaji., W. Kurniawan., K. Anwar., \& D. A, Kurniawan. "Effectivenes of Using E-Module and
E-Assessment", International Journal of Interactive Mobile Technologies (iJIM), Vol. 13, No. 9, pp. 21-39, 2019.

[25] Prasojo, Lantip Diat \& Riyant, "Teknologi Informasi Pendidikan”, Yogyakarta: Gava Media, 2011.

[26] N. Vyas., \& V. Nirban. "Students' Perception on the Effectiveness of Mobile Learning in an Institutional Context”, ELT Research Journal, Vol. 3, No. 1, pp. 26-36. 2014.

[27] A. Prawiradilaga, \& Handoko, "Mozaik Pendidikan E-Learning", Yogyakarta: Gava Media, 2013.

[28] Slameto, "Belajar dan Faktor-Faktor yangMemengaruhinya ", Jakarta: Rineka Cipta, 2003.

[29] D. Darmaji., D. A, Kurniawan., \& I. Irdianti. "Physics Education Students' Science Process Skills”, International Journal of Evaluation and Research in Education, Vol. 8, No. 2, pp. 293-298, 2019.

[30] Asrial., Syahrial., D.A. Kurniawan., F. Chan., R. Septianingsih., R. Perdana. Multimedia Innovation 4.0 in Education: E-Modul Ethnoconstrucivism. Universal Journal of Educational Research. 7(10), 2098-2107, 2019.

[31] P. Sinaga., Amsor, \& F. D, Cahyanti. "Effectiveness of the new generation e-book application for mobile phones in improving the conceptual mastery of kinematics", International Journal of Mobile Learning and Organisation, Vol. 13, No. 2, pp. 217-232. 2019.

[32] Darmaji, D. A. Kurniawan, Astalini, A. Lumbantoruan, and S. C. Samosir, "Mobile Learning in Higher Education for The Industrial Revolution 4.0 : Perception and Response of Physics Practicum", Int. J. Interact. Mob. Technol, Vol. 13, No. 9, pp. 4-20, 2019.

[33] Q. F, Yang., G. J, Hwang., \& H. Y, Sung. "Trends and research issues of mobile learning studies in physical education: a review of academic journal publications", Interactive Learning Environments, Vol.0, No. 0, pp. 1-19, 2018 .

[34] S. Wahyuni., \& N. Widiarti. "Penerapan pembelajaran berbasis masalah berorientasi chemo-entrepreneurship pada praktikum kimia fisika", Jurnal Inovasi Pendidikan Kimia, Vol. 4, No. 1, pp. 484-496, 2010.

[35] Syahrial., Asrial., D A. Kurniawan., F. Chan., A. Hariandi., R. A, Pratama., P. Nugroho., R. Septiasari. The Impact of Etnocontructivism in Social Affairs on Pedagogic Competences. International Journal of Evaluation and Research in Education (IJERE). 8(3), 409-416. 2019.

[36] Syahrial., Asrial., Husni, S., Arsil. Attitudes, Self-Confidence, and Independence of Students in Thematic Learning. Universal Journal of Educational Research. 8(1), 162-168, 2020.

[37] Syahrial., Asrial., L. G. Melinda., M. R. Fajar., N. Jannah., T. O. Puspitasari., Y. E. Putri. Impact E-Modul Ethnoconstructivism: Attitude \& Motivation. International Journal of Scientific \& Technology Research, vol. 9, no. 4, pp. 3752-3757, 2020.

[38] Asrial, Syahrial, D. A. Kurniawan, F. Chan., P. Nugroho., R. A. Pratama., R. Septiasari. Identification: The Effect of Mathematical Competence on Pedagogic Competency of Prospective Teacher. Humanities \& Social Science Reviews 
(HSSR). 7(4), 85-92, 2019

[39] R. S. Budiarti., Harlis., D. Natalia. High Oder Thinking Skills for Biology Education: Applied Microbiology Learning Videos Based on Jambi Local Wisdom. Universal Journal of Education Research, 8(2), 689-694. 2020

[40] H. H, Batubara. "Penggunaan Google Form Sebagai Alat Penilaian Kinerja Dosen di Prodi PGMI Uniska Muhammad Arsyad Al Banjari”, Jurnal Al Bidayah, Vol. 8, No. 1, pp. 39-40, 2016.

[41] T. Susanti., Damris., Maison., Tanti. Learning environment and motivation in junior high school. Universal Journal of Educational Research. 8(5), 2047-2056. 2020

[42] O. A, Nanda., \& I. Wilujeng. The Effectiveness of Android-assisted Optical Devices Learning to Improve Students' Conceptual Understanding, Jurnal Penelitian dan Pembelajaran IPA, Vol. 4, No. 2, pp. 105-115, 2018.

[43] A. I. W. I. Y, Sukmana., \& I. K, Suartama. "Pengembangan Mobile Learning Berorientasi Model Pembelajaran Flipped Classroom Pada Mata Kuliah Multimedia”, Journal of Education Technology, Vol.1, No. 2, pp. 45-50, 2018. 